\title{
1. Introduction: Aesthetics of Gentrification
}

\author{
Christoph Lindner and Gerard F. Sandoval
}

\begin{abstract}
This book examines the relationship between aesthetics and gentrification in contemporary cities from multiple, comparative, global, and transnational perspectives. In the introductory chapter, we argue that the aesthetics of gentrification produce sites of spectacular excess where the political economic forces driving urban redevelopment are empowered to remake space according to the needs of global capital. Through an analysis of the development of London's Greenwich Peninsula, we suggest that these forms of neoliberal, consumer-oriented aesthetics create seductive spaces and instil the desires needed to accelerate exclusionary urban transformations. The introductory chapter also considers the ways in which the aesthetics of gentrification now constitute a globalized, transnational phenomenon involving struggles for power in neoliberal urban contexts. We conclude that aesthetics increasingly function as a battleground where these urban spatial power struggles are played out through displacement, exclusion, and division.
\end{abstract}

Keywords: gentrification, aesthetics, neoliberal consumption, activism, urban renewal, race

\section{Seductive Spaces and Exclusive Communities}

The image featured on the book's cover (and reproduced below) was taken in 2019 at Greenwich Peninsula in southeast London shortly after the opening of a new linear park named The Tide (Figure 1.1). In the foreground, we see the end of The Tide's elevated walkway jutting out above a carefully manicured urban landscape. Various people are lounging around the park, some looking

Lindner, C. and G.F. Sandoval (eds), Aesthetics of Gentrification: Seductive Spaces and Exclusive Communities in the Neoliberal City. Amsterdam: Amsterdam University Press, 2021 DOI 10.5117/9789463722032_CHO1 


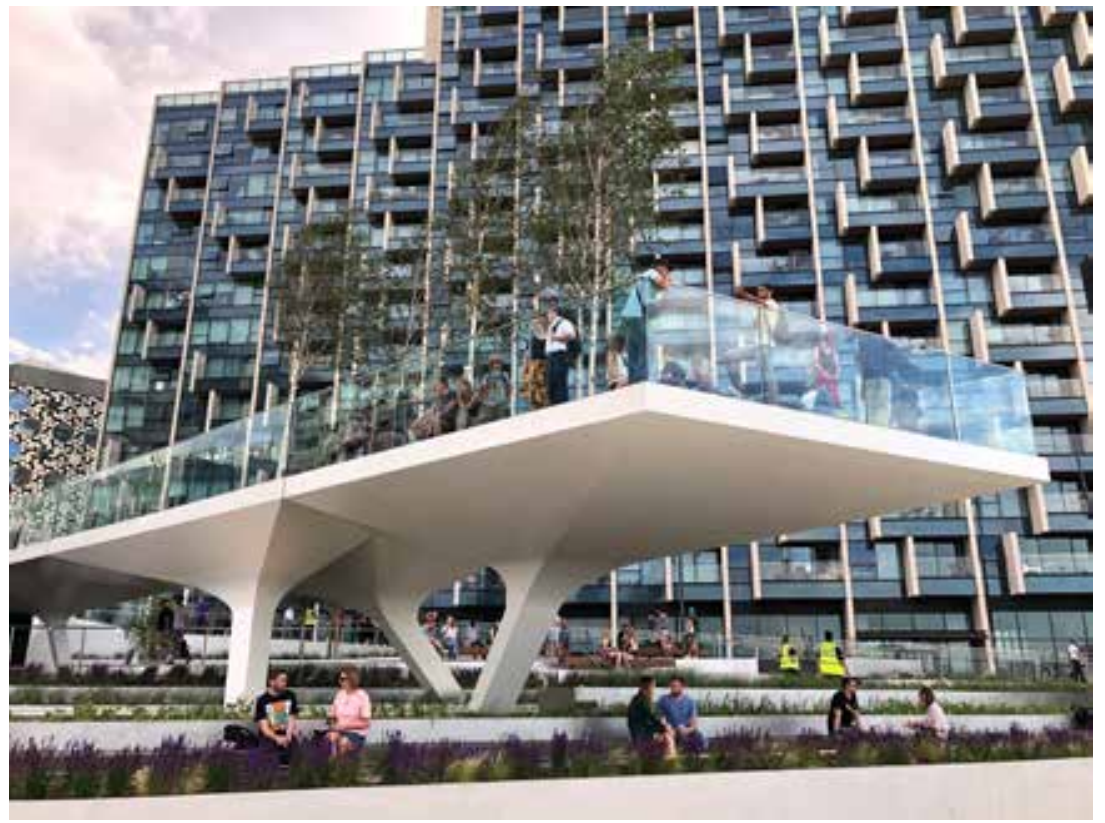

Figure 1.1: The Tide at Greenwich Peninsula. Photograph by Oliver Wainwright.

out at the riverside view from the elevated structure, others sitting in pairs beneath the structure immersed in conversation. In the background looms the glossy façade of a high-rise luxury apartment complex dominated by a geometric arrangement of mini balconies overlooking the scene of sociality and leisure staged below. We chose this image as it evokes the topic of this book: the aesthetics of gentrification and the ways in which those aesthetics are employed in neoliberal urban renewal strategies to create seductive spaces and exclusive communities. A closer look at Greenwich Peninsula and The Tide helps to bring these concerns into focus.

Completed in the summer of 2019 and designed by architects Diller Scofidio + Renfro, who famously co-designed the High Line elevated park in New York, The Tide marks the culmination of a decades-long effort to transform a stagnant site of postindustrial neglect into a vibrant, chic, and design-driven neighbourhood. The vision driving Greenwich Peninsula's transformation is articulated by the site's property developer, global placemakers Knight Dragon:

On Greenwich Peninsula London is transforming. Here is a new place inventing itself as the capital's most boldly modern landscape. An urban community with design and creativity embedded in its fabric. With 15,000 
new homes, 13,000 new jobs and 48 acres of open public space emerging over the coming years. Here a community of thousands of pioneers live in new riverside homes, work in a cutting-edge Design District and enjoy a new linear park The Tide - all wrapped by the river Thames. This is new London: a new destination for modern urban living. (Knight Dragon 2020)

Setting aside the promotional exuberance of this corporate sales pitch, the vision statement is revealing in the way it makes the case for the distinctiveness and novelty of the redevelopment project. Residents become "pioneers" joined together in a bold urban experiment aimed at forming a new community revolving around creativity (Smith 1982).

Not only does this vision replay Richard Florida's (2002) now tired argument about the regenerative power of the creative class, it also activates a rhetoric of settler colonialism by positing residents as homesteading adventurers - a trend long associated with gentrification and frequently tied to dynamics of race (Addie and Fraser 2019; Sandoval 2018; Lubitow et al. 2016; Osman 2011; Butler 2003). In short, despite all its claims to newness and invention, Greenwich Peninsula follows a well-established pattern of postindustrial revitalization supported by transnational global real-estate investments. The result is a neighbourhood ironically lacking in identity and originality - a site marked by flashy architecture, an abundance of pseudo-public space, predictable public art, corporate shopping and dining chains, superficial greenwashing, restricted mobility, and a general aura of affluence and placelessness.

As the area's symbolic centrepiece (Figure 1.2), The Tide exemplifies many of these qualities. Notably, the design of the park is conspicuously derivative (courtesy of the same architects involved in the High Line) and represents a fairly cynical example of a developer seeking to replicate the "High Line effect," whereby the creation of an elevated park sparks widespread public interest and unlocks rapid gentrification in the surrounding area (Lindner and Rosa 2017). Unsurprisingly, like most spin-off projects of this sort, The Tide falls flat in reproducing the success of the High Line. The prevalent view among architecture critics is that, unlike the High Line which adapts an abandoned freight railway for new public use, this park suffers from a lack of purpose, history, and meaning. City Lab's review, for instance, describes The Tide as an "exercise in pretty-but-functionless urbanism"; a "gangplank to nowhere"; an "expensive, heavily monitored add-on to a meretricious corporate development, possessing little in the way of either function or charm"; and an "infrastructural gewgaw to drum up a little attention for the blah condominium cluster that surrounds it" 


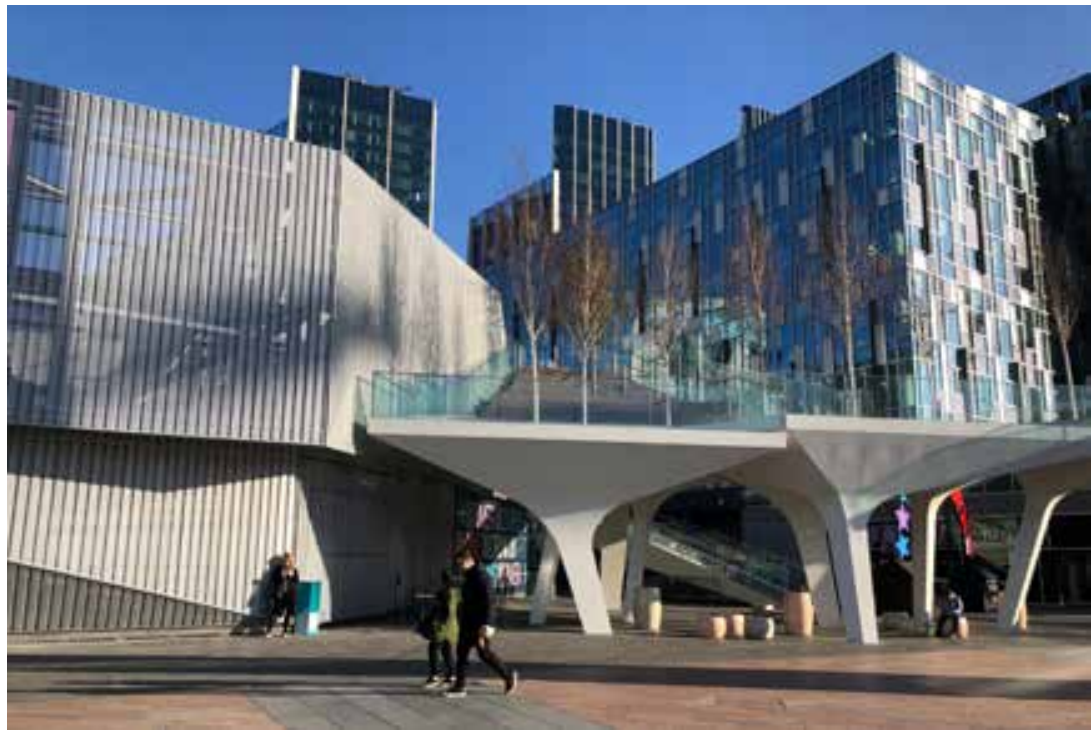

Figure 1.2: View from Peninsula Square. Photograph by Gerard Sandoval.

(O'Sullivan 2019). Similarly, Oliver Wainwright (who took the book's cover photograph) writes in his Guardian review that "when you're standing on the elevated deck, looking out over a jumbled vista of vents and service hatches, it's difficult to work out quite how anyone thought this was a good idea," adding that the walkway "has no purpose whatsoever, apart from providing a slightly different perspective on the surrounding carnage" (Wainwright 2019). He extends the critique to the entire area, which he characterizes as a "souped-up graveyard of novelty trinkets" and "junkyard of half-baked ideas and botched plans" (Wainwright 2019).

Among those ideas and plans is the Emirates Air Line cable car, a publicprivate partnership infrastructure project that transports tourists (and, theoretically, a very select subset of commuters) between Greenwich Peninsula and the Royal Docks business district across the River Thames (Figure 1.3). Built well before the residential redevelopment of North Greenwich during the 2012 London Olympic Games construction boom, this ostentatious caricature of a transportation project is not a functional piece of the city's everyday transportation system and attracts only a very small percentage of its passenger capacity (Saul 2013; Transport for London 2020). Rather, as suggested by the corporate partnership with Emirates, the cable car forms part of London's broader efforts to seduce global capital investment while boosting tourist appeal. The resulting spectacle of aerial-urban mobility has consequently attracted criticism for the way it contributes to London's 


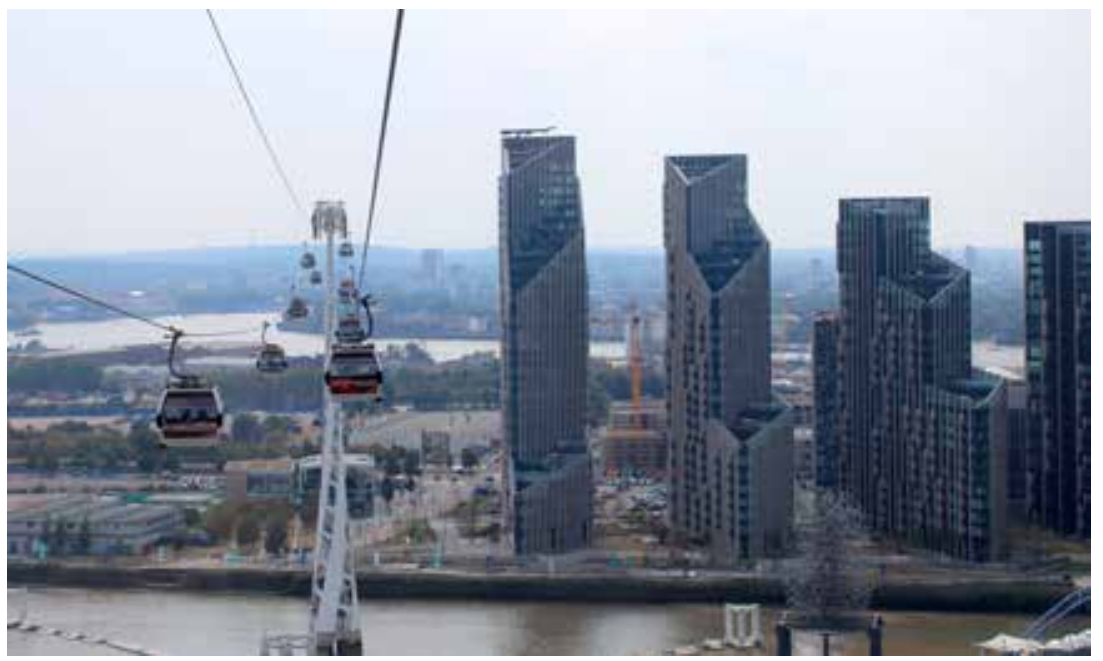

Figure 1.3: Emirates Air Line cable car, looking towards Greenwich Peninsula. Photograph by Hannah Lindner.

disneyfication. The cable car looks and functions like an amusement park ride, offering a carefully crafted experience of leisure, voyeurism, excitement, and distraction.

Interestingly, the interior of the gondolas is one of the only places where the Peninsula's history is explicitly told. As passengers cross above the river, a corporate promotional documentary is played on a screen inside, presenting a history of the area's redevelopment from one of London's principal ports through to its contemporary transformation into a chic, aesthetically polished neighbourhood. When crossing from Greenwich into East London, the history tour ends with a detailed description of The Crystal, a large events venue located adjacent to the Royal Docks cable car station that is marketed as "one of the world's most sustainable buildings." The Crystal building is an example of investment in East London's real estate transformation and a case study in greenwashing in commercial redevelopment. As such, the Emirates Air Line can be seen as a literal and symbolic line connecting two postindustrial sites sharing the same neoliberal approach to urban revitalization.

As an example of gentrification, Greenwich Peninsula is perhaps not among the most obvious in London. Hipsterized neighbourhoods such as Shoreditch, Hackney, and Peckham, to name a few, conform more closely to the conventional model of local residents being displaced by a more socio-economically privileged population. Because Greenwich Peninsula was built on disused industrial land, the development is less a site of direct displacement 
and more an aestheticized space of exclusive living and consumption that precludes alternative and more inclusive ways of creating, inhabiting, or experiencing the neighbourhood. Even so, Greenwich Peninsula contributes to, and is symptomatic of, a wider process of gentrification unfolding across the city, a trend marked by the proliferation of unaffordable housing and an accompanying decrease in mixed-income populations. In many ways, Greenwich Peninsula epitomizes the ultimate end of the neoliberal city - a site of spectacular excess where the forces of development have been empowered to remake space according to the needs of global capital. The role of aesthetics in creating such exclusive and seductive transformations is the focus of this book's engagement with gentrification.

\section{Gentrification, Globalization, Aesthetics}

Gentrification is widely studied across disciplines in the social sciences, humanities, and art and design fields. Within existing scholarship, the topic is predominantly approached from economic, geographic, planning, sociological, and related social-scientific perspectives (Freeman 2005; Lees et al. 2010; Zukin 1987; Zuk et al. 2017). These perspectives are vital to understanding the forces, conditions, and effects of gentrification on cities and communities, and over the last several decades - but particularly in the present era of neoliberal globalization and accelerated urbanization - they have yielded key insights into dynamics of urban displacement and exclusion in locations around the world. Indeed, the rise of "planetary gentrification," to use the term developed by Loretta Lees, Hyun Bang Shin, and Ernesto López-Morales (2016), has seen not only a global proliferation of neoliberal urban redevelopment, but also increasing transnational synchronization of the processes involved. The effect is that, as Lees (2019) argues, "gentrification is no-longer, if it ever was, a small scale process of urban transformation," but "globally is more often than not practiced as large scale urban redevelopment" and "is now predominantly state-led or state-induced" (7). Gentrification, in short, has gone global and is now part of what Saskia Sassen (2014) describes as "the new logics of expulsion" (1) driving the global economy.

In this book, we aim to expand on these analytical perspectives by additionally examining the roles that exclusion and seduction play within the aesthetics of gentrification. We argue that aesthetics are integral to the global story of gentrification, particularly in the way aesthetics are increasingly being used - via neoliberal consumerism (Castro 2015) - to produce the seductive conditions and instil the desires needed for creating exclusionary 
urban transformations predicated on displacing and disempowering vulnerable populations. Although the authors in this book approach aesthetics from a range of theoretical perspectives, it is fair to say that the volume as a whole does cohere around a broad understanding of aesthetics as a visual regime in the sense that Jacques Rancière gives to the concept: aesthetics as politics and comprising "forms of visibility that disclose artistic practices, the place they occupy, what they 'do' and 'make' from the standpoint of what is common to the community" (Rancière 2004: 13). At stake therefore in our various analyses of the aesthetics of gentrification is not only greater understanding of the social-spatial politics of cities but also new insight into the subjects and operations of urban power (Foucault 1982).

Although they examine a geographically and culturally diverse range of case studies, the chapters in this book have certain themes in common. First, we understand the aesthetics of gentrification as an increasingly transnational phenomenon involving struggles for power in neoliberal urban contexts. Second, we are alert to how urban redevelopment actively produces spaces of desire and seduction that deliberately look and feel constructed in order to create gentrification effects that encourage mobility and exploit displacement of low-income populations. Third, we see aesthetics as increasingly being one of the battlegrounds where these urban spatial power struggles are played out through displacement, exclusion, and division. And finally, we are sensitive to the ways in which people become complicit - both consciously and inadvertently - with gentrification processes and their seductive elements. To pursue these concerns, we have organized the book's chapters into three interconnecting thematic groupings: spaces of global consumption; anxiety and visibility; and agency, voices, and activism.

\section{Spaces of Global Consumption}

Part 1, "Spaces of Global Consumption," focuses on how gentrification encompasses processes of neoliberal consumption involving housing, cultural entertainment, retail experience, and the aesthetics of placemaking. Together, the chapters in Part 1 demonstrate how the aesthetics of gentrification are manifested in spaces of consumerism and circulate globally. The emphasis in Part 1 is on visual culture, architecture and design, and the importance of local narratives in supporting global market conditions.

In the opening chapter of Part 1 , "The Forces of Decline and Regeneration," Samuel Zipp, Jennifer Hock, and Nate Storring revisit Jane Jacobs' legacy in light of twenty-first-century urban dynamics. In particular, they draw 
on Jacobs' three concepts of the "sidewalk ballet," "organized complexity," and the "self-destruction of diversity" to help situate her work in relation to contemporary aesthetics of gentrification. One crucial issue that emerges in their discussion is Jacobs' understanding and writing on issues of race, which is an area of her work that has been underexamined by scholars. Zipp, Hock, and Storring's analysis of Jane Jacobs is an important starting point for the book's overall consideration of how the aesthetics of gentrification are reshaping cities. Key concerns, for example, include how Jacobs' thinking relates to neighbourhood aesthetics, neighbourhood building types, residents' access to a diverse range of mobility options, and locally-based commercial retail, which all contribute to the uniqueness of neighbourhoods yet have also become foundational building blocks for gentrification.

In "Silicon Wafers and Office Park Dreams," Jenny Lin critiques the visual culture of California's Silicon Valley and the intellectual milieu of the information age. Her historical analysis traces the morphing of global software design giants, such as Apple and Google, into visually monolithic buildings expressing a corporate structure based on collaboration, experimentation, and a horizontally-based management structure. Lin argues that Silicon Valley's circulatory global corporate aesthetics contribute to a context of placelessness, economic inequality, and displacement. Here, the aesthetics of gentrification emerge from an unlikely space - one of intellectual collaboration operating within a local context concerned with reclaiming multiculturalism and resisting gentrification.

Guillaume Sirois considers the aesthetics of gentrification produced in and around boutiques in Montreal's Mile End District. In his chapter on "Selling Authenticity," he maps the interconnections between the global flows of neoliberal consumption and the commodification of local culture. Sirois demonstrates how the aesthetics of gentrification in this boutique district manifest through the constructed values of authenticity, materiality, and hospitality. As he reveals, locally-designed products often signify to buyers a break with the global market economy, when in fact those products ultimately complement and reinforce larger dynamics of neoliberal globalization.

The final chapter of Part 1 traces the revitalization of a neighbourhood in República, a district in the central area of the Brazilian city of São Paulo. In "The Import of a Narrative," Beatriz Kalichman and Beatriz Rufıno analyze the aesthetics and discursive elements in the neighbourhood's transformation from quitinetes (worker housing built in the 1950s and 6os) toward more affluent studio apartments. Kalichman and Rufino argue that the aesthetics of gentrification in República hinge on emulating the postindustrial 
transformation of SoHo in New York City in the 1970s. Their case study points to the links between aesthetics and planetary gentrification as cities in the global south seek to replicate visual and spatial patterns of neoliberal urban renewal via a circularity of global capital in real estate development.

\section{Anxiety and Visibility}

Part 2, "Anxiety and Visibility," traces the shadow side of gentrification in a sequence of chapters that reveal the often discriminatory nature of urban redevelopment. Through a diverse set of case studies, the authors address issues of racialized gentrification, xenophobia, and "othering" present in gentrification processes and their accompanying aesthetics. The broader idea developed in Part 2 is that gentrification is not limited to the cultural-spatial change seen in a transforming neighbourhood, but can involve a deeper shift in that neighbourhood's milieu of belonging reflective of racial and ethnic composition.

In her chapter on Washington D.C., Brandi Thompson Summers analyzes a mainly Black neighbourhood experiencing rapid gentrification. She problematizes ideas of "diversity" by demonstrating how a convergence of hipster aesthetics within a Black cultural space has resulted in the displacement of many Black low-income residents. As her analysis reveals, the gentrification process in this Black cultural space exploits a concept of authenticity in which people attach meaning to things (instead of the experiences of people), leading in turn to racialized gentrification as young, upper-income whites settle into the neighbourhood.

In "Art and the Aesthetics of Cultural Gentrification," Jonathan Jaean Crisman follows up with two Los Angeles-based case studies: Boyle Heights and Little Tokyo. Crisman assesses the role art is playing in cultural gentrification within these two diverse contexts. The chapter traces how an arts-based aesthetics of engagement opens up opportunities for these communities to shape the gentrification process. Crisman argues that these forms of aesthetics link ethics, collective interaction, and participatory community development. He ends on an optimistic note, stressing that these cultural places can open up new potentials in combating the atomizing effects of gentrification.

Maintaining the focus on Los Angeles, Susanna Newbury's chapter examines the art performance of Susan Silton who locates her work in a gentrifying neighbourhood in the city. Silton's work relates to aesthetics as representation as it is based on a performance practice of ethical imperative within reparative witnessing, which helps individuals see and account 
for their roles in historic forms of crisis (such as the roles played within gentrification). Newbury argues that Silton's LA-based performances make a connection between the crises brought about through global neoliberal consumerism and its grounding within gentrifying neighbourhoods.

In "Satellite Dishes, a Creative Incubator, and the Displacement of Aesthetics in Amsterdam," Daan Wesselman provides examples of how the aesthetics of gentrification contribute towards reifying "otherness" within Amsterdam's Bos en Lommer neighbourhood. He details the different treatment of immigrant tenements as they become defined in aesthetic terms through xenophobic expressions. Wesselman distinguishes the aesthetic value given to the non-white part of a neighbourhood with satellite dishes attached to social housing and compares that to the aesthetic value given to the part of the same neighbourhood without immigrants. This analysis directly demonstrates the xenophobia enacted through the aesthetics of gentrification and the active role that art, fashion, and consumption play in the neighbourhood's division. Wesselman argues that the newly-inserted globalized aesthetics of gentrification - following the typical creative incubator formula - displace the political battle over otherness occurring across the street.

\section{Agency, Voices, and Activism}

Part 3, "Agency, Voices, and Activism," foregrounds the emergence of representational politics in certain forms of anti-gentrification movements. These anti-gentrification struggles push back in diverse ways as activists respond to new or growing inequalities created through neoliberal urban redevelopment. A particular concern in Part 3 is the relationship between gentrification and racialized spaces, including the displacement of marginalized populations as a consequence of emerging hipster consumerist spaces. These urban conflicts have, in turn, activated agency and voice for anti-gentrification political movements.

In "Boulevard Transition, Hipster Aesthetics, and Anti-Gentrification Struggles in Los Angeles," Jan Lin provides an insightful study of Boyle Heights' rapid gentrification and the community resistance against that transformation. As Lin explains, residents in Boyle Heights, a historically Latinx neighbourhood, have fought back against arts-based gentrification. In particular, they have experienced the co-optation of the neighbourhood's Latinx ethnic identity by hipster entrepreneurs seeking to profit not only from new public infrastructure investments in the area, but also from the neighbourhood's edgy diversity. In response, Latinx grassroots activist 
organizations have engaged in a neighbourhood-based anti-gentrification movement as they view the new art galleries and hipster aesthetics as threats to their community. Moreover, Lin argues, the activist organizations have struggled to gain ground and lay claim to their space despite deploying an anti-gentrification toolkit encompassing community-based art and theatre.

Gillian Jein considers the aesthetics of gentrification through analysis of street art and spatial politics in the Parisian banlieues. In "Speculative Spaces in Grand Paris," she highlights the ways in which long-standing political and racial tensions between the centre and peripheries of the city are accentuated, critiqued, and destabilized by artists working against the backdrop of state-led urban redevelopment. Focusing on the work of JR, a street artist who combines large-format photography with the provocative ethos of graffiti, Jein shows how public art installations can bring gentrification into view by expressing the tensions involved in neighbourhood change.

Rebecca Amato argues in "On Empty Spaces, Silence, and the Pause" that the production of empty spaces in New York City is a crucial component of gentrification. Amato demonstrates that techniques such as filtering, investing in the aesthetic potential of ageing neighbourhoods, and declaring vacancy, have all helped to fuel gentrification. As she discusses, New York City encourages the development of underutilized land parcels for high-rises, green sustainable construction, and increased density. Amato contrasts these trends against the activist efforts to provide alternative, more inclusive models of urban redevelopment based on cooperative centres and community gardens.

The book's final chapter examines confluences between mobility, technology, and gender in the urban peripheries of Delhi. In "The 'Smart Safe City" Ayona Datta extends existing thinking on gentrification by considering the ways in which new forms of "technocratic gentrification" have emerged in the global south as a result of the rise of smart cities and postcolonial urbanism's dependence on acceleration and speed. In particular, she presents findings from an innovative research project that uses mobile technology and social media to support young women negotiating precarious lives in Delhi's digital and urban margins. Datta argues that their everyday mobility across the city highlights the ambiguities and paradoxes of their lives, including tensions between belonging and exclusion.

\section{Investigating Gentrification}

The aesthetics of gentrification are rapidly transforming cities. These changes are both cultural and material. Culturally, the aesthetics of gentrification 
transform the milieu of a place by adding to the displacement of low-income populations, racially marginalized ethnic groups, and other vulnerable populations priced out of their neighbourhood. Materially, the transformations are physical via investments in infrastructure, the redesigning of public spaces, and the building or rehabilitating of housing. Whether culturally or materially, these rapidly transforming spaces are ones of seduction and exclusion.

In the following chapters, we explore how seduction has played an essential role in attracting both people and capital to neighbourhoods labelled as "edgy," "ethnically diverse," "cool," "hipster." We also explore what happens when conditions of seduction collide with the political environment of local activists trying to stop or reroute gentrification. In terms of exclusion, the aesthetics of gentrification create spaces that are unavailable, inaccessible, or unaffordable for either existing residents or incoming populations. There may not be walls around these new developments, but as the Greenwich Peninsula example shows, the combination of flamboyant architecture, restricted mobility, and ambiguity over whether open space is public or private all contribute to forming an aesthetic of exclusion.

Our goal for this book is to encourage new dialogue on the aesthetics of gentrification, both within and beyond social science studies of gentrification. In our thinking, the chapters published here elicit crucial questions that should be further analyzed, theorized, and debated. First, who are the financiers of transnational gentrification projects? What proportion of the capital is being supplied transnationally via multinational corporations? Second, what other forms and methods of seduction and exclusion exist that have not been surfaced in this book? Third, how are the emerging antigentrification transnational social movements affecting the redevelopment and consequent transformation of neighbourhoods? Furthermore, to what extent can vulnerable populations increase their agency to secure benefits from the aesthetics of gentrification? Is this even possible? And, lastly, what role does racialization continue to play in the aesthetics of gentrification within a global Black Lives Matter movement?

This last question on racialization is critical to answer and, alongside the other questions raised above, we examine the role of racism in gentrification throughout several chapters. Summers' study directly focuses on this issue through her discussion of the transformation of a Black community in Washington D.C. into a higher income multiracial neighbourhood where Blackness is accepted but represents a generic form of diversity that becomes commodified. In addition, Zipp, Hock, and Storring discuss how Jane Jacobs approached issues of race, which represents a fresh perspective on Jacob's work. Jein follows the racialized making (and unmaking) of the Parisian 
banlieues as dangerous and deviant no-go zones. And Wesselman analyzes xenophobic processes tied to the aesthetics of satellite dishes in Amsterdam. These authors make the clear connection between racism in the aesthetics of gentrification and the "othering" of places.

Another important theme running through many of the chapters is the emergence and value of activism and transnational social movements. This is evident, for example, in Lin's analysis of the community activism in Boyle Heights, Crisman's discussion of anti-arts protest, and Newbury's focus on artist-led critiques and resistance. Social activism against gentrification or tenant right protests, or even efforts to maintain the ethnic symbolism of neighbourhoods, are on the rise globally. The book's examples span the United States, Britain, Brazil, Canada, India, The Netherlands, and France, and demonstrate the pivotal role social movements and "the revolt of the excluded" (Dikec 2017) can play in both resisting and reinforcing the aesthetics of gentrification.

These anti-gentrification movements constitute rebellious communities whose activist efforts to halt gentrification can make those spaces appear - at least superficially - more exciting, edgy, and attractive. Ironically, this frequently ends up contributing to gentrification because the atmosphere of resistance tends to increase the seductive capacity and cultural value of the neighbourhood, leading to the dispossession of original residents through rising rents and increased property taxes (Harvey 2012: 77-8). The implication is that the appeal of counterculture and the allure of "authentic local places" (Zukin 2009) are drivers of gentrification - hence our use of the phrase "seductive spaces and exclusive communities" in the book's title. For example, Sirois points out a contradiction he observes in Montreal's small boutiques. As he discusses in his chapter, these boutiques in a rapidly gentrifying neighbourhood cater to customers seeking unique local products as an alternative to the global economy, but the boutiques are actually plugged into and directly support the global consumer market. As this suggests, the aesthetics of gentrification can play a subtle yet influential role in maintaining contradictions that ultimately benefit neoliberal urban redevelopment.

Gentrification itself is now a structural condition of transition within cities across the world. It relies on a neoliberal, consumer-based population that is rapidly transforming neighbourhoods. As detailed throughout the book, gentrification commodifies local culture, creates inauthentic local narratives, and leads inexorably to displacement and expulsion. Three key elements are implicated in these processes: transnational neoliberal consumerism, global capital financing of the real estate market, and local 
anti-gentrification social movements trying to resist these forces. All of these entangling elements combine to create eruptions of accelerated urban change. These urban transformations threaten to create neighbourhoods lacking uniqueness, an established history, or a sense of purpose and meaning. They lead to new forms of urban placelessness that impede belonging, reinforce exclusion, and further embed structural mechanisms of global inequality.

\section{Works Cited}

Addie, Jean-Paul D. and James C. Fraser (2019) "After Gentrification: Social Mix, Settler Colonialism, and Cruel Optimism in the Transformation of Neighbourhood Space." Antipode 51.5: 1369-1394.

Butler, Tim (2003) "Living in the Bubble: Gentrification and its 'Others' in North London." Urban Studies 40.12: 2469-2486.

Castro, J.C.L. (2015) “The Consumer as Agent of Neoliberalism." Matrizes, São Paulo 9.2: $273-288$.

Dikec, Mustafa (2017) Urban Rage: The Revolt of the Excuded. New Haven: Yale University Press.

Florida, Richard (2002) The Rise of the Creative Class. New York: Basic Books.

Foucault, Michel (1982) “The Subject of Power." Critical Inquiry 8.4: 777-795.

Harvey, David (2012) Rebel Cities: From the Right to the City to the Urban Revolution. London: Verso.

Knight Dragon (2020) “Vision.” Greenwich Peninsula. Retrieved from: https://www. greenwichpeninsula.co.uk/about/vision (accessed 16 April 2020).

Freeman, Lance (2005) "Displacement or Succession? Residential Mobility in Gentrifying Neighborhoods.” Urban Affairs Review 40.4: 463-491.

Lees, Loretta (2019) "Planetary Gentrification and Urban (Re)Development." Urban Development Issues 61: 5-13.

Lees, Loretta, Tom Slater and Elvin K. Wyly (eds) (2010) The Gentrification Reader. London: Routledge.

Lees, Loretta, Hyun Bang Shin and Ernesto López-Morales (2016) Planetary Gentrification. Cambridge: Polity Press.

Lindner, Christoph and Brian Rosa (eds) (2017) Deconstructing the High Line: Postindustrial Urbanism and the Rise of the Elevated Park. New Brunswick: Rutgers University Press.

Lubitow, Amy, Bryan Zinschlag and Nathan Rochester (2016). "Plans for Pavement or for People? The Politics of Bike Lanes on the 'Paseo Boricua' in Chicago, Illinois." Urban Studies 53.12: 2637-2653. 
Miriam Zuk, Ariel H. Bierbaum, Karen Chapple, Karolina Gorska and Anastasia Loukaitou-Sideris (2017) "Gentrification, Displacement, and the Role of Public Investment." Journal of Planning Literature 33.1: 31-44.

O’Sullivan, Feargus (2019) “That Sinking Feeling: London's 'Tide' Disappoints.” City Lab, 11 July 2019. Retrieved from: https:/www.citylab.com/design/2019/07/ london-tide-park-diller-scofidio-renfro-landscape-design/593620 (accessed 16 April 2020).

Osman, Suleiman (2011) The Invention of Brownstone Brooklyn: Gentrification and the Search for Authenticity in Postwar New York. Oxford: Oxford University Press.

Rancière, Jacques (2004) The Politics of Aesthetics: The Distribution of the Sensible, trans. G. Rockhill. London: Continuum.

Sandoval, Gerardo (2018) "Planning the Barrio: Ethnic Identity and Struggles over Transit-Oriented, Development-Induced Gentrification." Journal of Planning Research and Education. https://doi.org/10.1177/0739456X18793714

Sassen, Saskia (2014) Expulsions: Brutality and Complexity in the Global Economy. Cambridge, MA: Harvard University Press.

Smith, Neil (1982) “Gentrification and Uneven Development." Economic Geography. 58: 139-155.

Saul, Heather (2013) “Boris Johnson’s £6om Cable Cars Used Regularly by Just Four Commuters.” The Independent, 22 November. Retrieved from: https://www. independent.co.uk/news/uk/politics/boris-johnsons-6om-cable-cars-usedregularly-by-just-four-commuters-8954646.html (accessed 16 April 2020)

Transport for London (2020) “Emirates Air Line Passenger Journeys.” Retrieved from: https://tfl.gov.uk/corporate/publications-and-reports/emirates-air-linepassenger-journeys (accessed 16 April 2020).

Wainwright, Oliver (2019) “London's Answer to New York's High Line? You Must be Joking." The Guardian, 10 July. Retrieved from: https://www.theguardian. com/artanddesign/2019/jul/10/tide-elevated-walkway-greenwich-peninsulalondon-new-york-high-line (accessed 16 April 2020).

Zuk, Mariam, Ariel Bierbaum, Karen Chapple, Karolina Gorska and Anastasia Loukaitou-Sideris (2017) "Gentrification, Displacement, and the Role of Public Investment." Journal of Planning Literature. 33.1: 31-44.

Zukin, Sharon (1987) "Gentrification: Culture and Capital in the Urban Core." Annual Review of Sociology 13.1: 129-47.

Zukin, Sharon (2009) Naked City: The Death and Life of Authentic Urban Places. New York: Oxford University Press. 
About the Authors

Christoph Lindner is Professor of Urban Studies and Dean of The Bartlett Faculty of the Built Environment at University College London, where he writes about cities, globalization, and social-spatial inequality.

Gerard F. Sandoval is an Associate Professor in the School of Planning, Public Policy and Management at the University of Oregon. His research focuses on the roles of immigrants in community regeneration, the urban planning interventions of governments in low-income immigrant communities, and the transnational relationships that exist within immigrant neighbourhoods. 